\title{
ROLA KONSERWATORA WOJEWÓDZKIEGO W OCHRONIE I ZARZĄDZANIU POMNIKIEM HISTORII NA PRZYKŁADZIE WARSZAWY I MAZOWSZA
}

\section{LEWICKI Jakub ${ }^{1}$}

\footnotetext{
${ }^{1}$ prof. Jakub Lewicki, Zakład Konserwacji Zabytków i Ochrony Krajobrazu UKSW https://orcid.org/0000-0003-1766-659X
}

ABSTRAKT: W tekście omówiono rolę Konserwatora Wojewódzkiego w ochronie i zarządzaniu pomnikiem historii na przykładzie działań w Warszawie i na Mazowszu. Najważniejszą rolą Wojewódzkiego Konserwatora Zabytków jest pełnienie nadzoru konserwatorskiego nad zabytkami znajdującymi się na terenie pomnika historii. W ten sposób WKZ może upowszechniać wysokie standardy prowadzonych prac konserwatorskich i tworzyć wzorce ochrony i konserwacji na tym obszarze, a także prowadzić działania promocyjne. Omówiono wszystkie obiekty będące pomnikami historii z terenu Mazowsza, a także złożone wnioski i wymieniono te zabytki, które zasługują na rangę pomnika historii. Mimo narzuconych prawnie ograniczeń Wojewódzki Konserwator Zabytków może aktywnie działać na rzecz ochrony pomników historii i być wykonawcą polityki państwa dotyczącej narodowego dziedzictwa. Może też bardzo sprawnie łączyć zrównoważony rozwój obszarów pomników historii z ochroną konserwatorską i z rozwojem oraz z przystosowaniem ich do zmieniających się potrzeb życia.

SŁOWA KLUCZE: Pomniki historii, Warszawa, Żyrardów, Płock, Pułtusk, Czersk, Opactwo koło Sieciechowa, Krasne, Brochów, Sulejówek, Czerwińsk nad Wisłą, Radom, Węgrów, Iłża, Szydłowiec, Porzecze Mariańskie

Wojewódzki Konserwator Zabytków może pełnić różne funkcje chroniąci zarządzając pomnikiem historii. Najważniejszą jego rolą jest pełnienie nadzoru konserwatorskiego nad zabytkami znajdującymi sięna tym terenie. Dlatego też może tworzyć wzorce ochrony i konserwacji zabytków na tym obszarze. Może też podejmować prace na rzecz ochrony i konserwacji zabytków pomnika historii oraz inicjować działania na rzecz uznania za pomnik historii. Aby w pełni ukazać rolę Wojewódzkiego Konserwatora Zabytków najpierw przedstawiono zasób pomników historii na Mazowszu i ich problemy konserwatorskie. Następnie zaprezentowano wykaz wniosków złożonych z inicjatywy MWKZ o uznanie za pomnik historii. Wreszcie zaprezentowano też zespoły, które powinny być uznane za pomnik historii na Mazowszu. Podsumowanie pracy stanowią uwagi na temat roli MWKZ w ochronie i zarządzaniu pomnikami historii. Podkreślono 


\section{Jakub Lewicki}

działania na tych obszarach, które łączą ochronę konserwatorską z rozwojem i przystosowaniem się tych terenów do zmieniających się potrzeb życia.

\section{Pomniki historii na Mazowszu}

Według stanu na początek czerwca 2019 roku na Mazowszu znajduje się 6 pomników historii. Są to:

- historyczny zespół miasta z Traktem Królewskim i Wilanowem w Warszawie uznany za pomnik historii 8 września $1994 \mathrm{roku}^{1}$. Jak napisano w uzasadnieniu uznania za pomnik historii Zamek Królewski, Stare i Nowe Miasto, Krakowskie Przedmieście były widownią najdonioślejszych wydarzeń historycznych. Założenia przestrzenne cechuje bogactwo rozwiązań architektonicznych, sztuki ogrodowej, rzeźby i rzemiosła artystycznego stosowanego w architekturze, rzeźbie i pomnikach. Dają świadectwo wysokiego poziomu artystycznego działających w stolicy na przestrzeni wieków urbanistów, architektów, artystów i rzemieślników². Cały zespół wymaga nieustannego nadzoru konserwatorskiego, a prowadzone na tym terenie prace remontowe i konserwatorskie musi cechować najwyższy poziom.

- Żyrardów - XIX-wieczna Osada Fabryczna uznana za pomnik historii 4 stycznia 2012 roku (Ryc. 1).

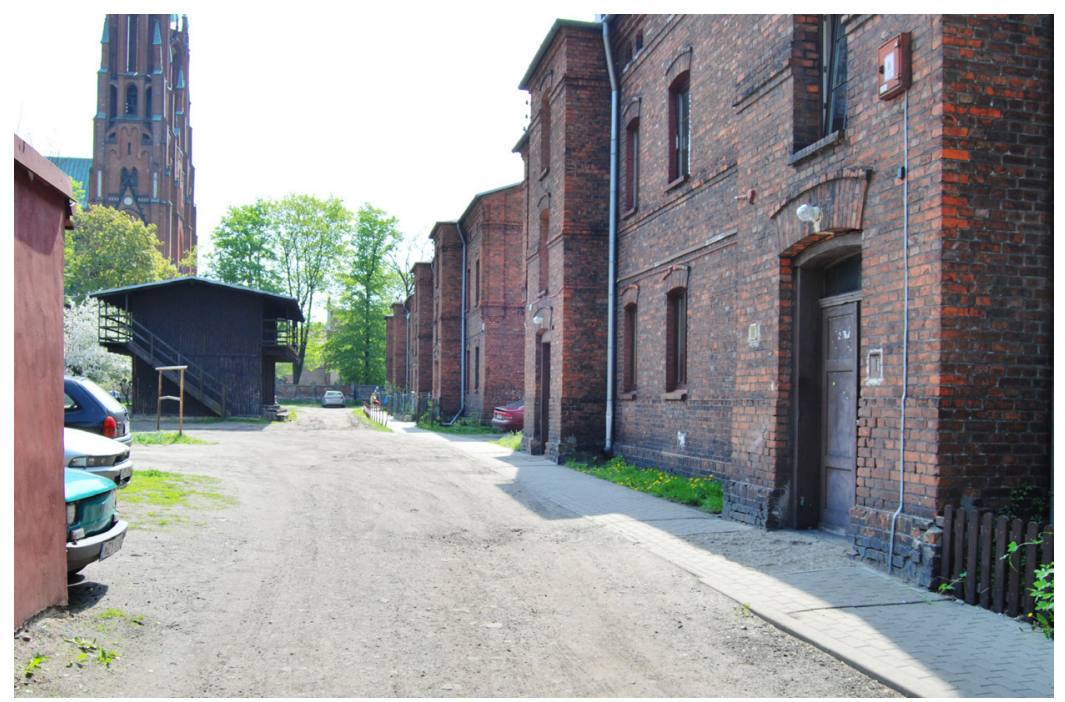

Fot. 1 Żyrardów, XIX-wieczna Osada Fabryczna, stan w 2014 roku, domy robotnicze.

Fot. J. Lewicki

Zarządzenie Prezydenta RP z 8 września 1994 r. w sprawie uznania za pomnik historii, „Monitor Polski”, 1994, nr 50, poz. 423.

2 https://www.nid.pl/pl/Informacje_ogolne/Zabytki_w_Polsce/Pomniki_historii/Lista_miejsc/miejsce. php?ID=317, data wejścia $15 \mathrm{~V} 2019$.

Rozporządzenie Prezydenta RP z dnia 4 stycznia 2012 r. w sprawie uznania za pomnik historii „Żyrardów - XIX-wieczna Osada Fabryczna”, Dz. U., 1912, Nr 11, poz. 59. 
W uzasadnieniu napisano, że osada fabryczna w Żyrardowie jest niezwykle cennym świadectwem ponad stuletnich lniarskich tradycji tego miasta i przykładem jego związków z przemysłem włókienniczym Królestwa Polskiego. O wyjątkowości założenia urbanistycznoarchitektonicznego Żyrardowa stanowi jego autentyczność. Zachowała się pierwotna kompozycja przestrzenna oraz większość zabudowy. Zmiana funkcji obiektów fabrycznych, biorąc pod uwagę najnowszą historię dawnego potentata przemysłu lniarskiego i nieubłagane mechanizmy ekonomii, stała się natomiast sposobem na ochronę tkanki miejskiej Żyrardowa, pozwalającym zachować jego pierwotną strukturę historycznego ośrodka przemysłowego ${ }^{4}$. Cały zespół wymaga kompleksowej ochrony przed przekształceniami, co dotyczy szczególnie zabudowy miasta jak i dawnych zakładów przemysłowych.

- zespół Stacji Filtrów w Warszawie Williama Lindleya uznany za pomnik historii 4 stycznia $2012 \mathrm{roku}^{5}$. Jak stwierdzono w uzasadnieniu, zespół ten jest unikatem w skali Europy ze względu na doskonały stan zachowania i użytkowanie zgodne z pierwotnym przeznaczeniem. Stanowi on wybitny zabytek techniki świadczący o wysokim poziomie nowatorskiej myśli technicznej. Rozwiązania technologiczne i architektoniczne zabudowań Stacji Filtrów, interesująca kompozycja przestrzenna, a przede wszystkim trwałość substancji, zachowanie funkcji oraz perspektywiczny charakter tej realizacji świadczą o jej fenomenie i najwyższych wartościach zabytkowych ${ }^{6}$. Cały zespół wymaga kompleksowej ochrony jak i bardzo starannego prowadzenia prac remontowych i konserwatorskich.

- zespół zabytkowych cmentarzy wyznaniowych na Powązkach w Warszawie uznany za pomnik historii rozporządzeniem z 3 lipca 2014 roku$^{7}$. W uzasadnieniu napisano, że cmentarze te odznaczają się wyjątkowymi wartościami historycznymi i artystycznymi. Skupisko historycznych cmentarzy wyznawców chrześcijaństwa, judaizmu i islamu jest zjawiskiem wyjątkowym w skali europejskiej i w sposób jednoznaczny świadczy o bogactwie polskiego dziedzictwa kulturowego. Zespół jest wielką galerią rzeźby odzwierciedlającą $\mathrm{w}$ formach znajdujących się na nim nagrobków historię rozwoju sztuk plastycznych od końca XVIII do XX wieku8. Wszystkie cmentarze wymagają nieustannego nadzoru konserwatorskiego, a prowadzone prace konserwatorskie musi cechować najwyższy poziom.

\footnotetext{
https://www.nid.pl/pl/Informacje_ogolne/Zabytki_w_Polsce/Pomniki_historii/Lista_miejsc/miejsce. php?ID=324, data wejścia 15 V 2019.

Rozporządzenie Prezydenta RP z dnia 4 stycznia 2012 r. w sprawie uznania za pomnik historii „Warszawa - Zespół Stacji Filtrów Williama Lindleya”, Dz. U., 18 stycznia 2012, poz. 64.

6 https://www.nid.pl/pl/Informacje_ogolne/Zabytki_w_Polsce/Pomniki_historii/Lista_miejsc/miejsce. php?ID=318, data wejścia $15 \mathrm{~V} 2019$.

Rozporządzenie Prezydenta RP z dnia 3 lipca 2014 r. w sprawie uznania za pomnik historii „Warszawa zespół zabytkowych cmentarzy wyznaniowych na Powązkach”, Dz. U., 21 lipca 2014, poz. 956.

8 https://www.nid.pl/pl/Informacje_ogolne/Zabytki_w_Polsce/Pomniki_historii/Lista_miejsc/miejsce. php?ID=2398, data wejścia $15 \mathrm{~V} 2019$.
} 
- Wzgórze Tumskie w Płocku uznane za pomnik historii 20 kwietnia 2018 roku9

Jak stwierdzono w uzasadnieniu, Płock należy do najstarszych i najważniejszych ośrodków miejskich w Polsce, określanych w XI w. przez Galla Anonima jako: sedes regni principalis, czyli ośrodki, w których rezydowali władcy. Za czasów Władysława I Hermana oraz jego synów Zbigniewa i Bolesława III Krzywoustego Płock stał się główną rezydencją monarszą w kraju, jednocześnie - miejscem fundacji książęcych i kościelnych, a katedra płocka - nekropolią władców. Po podziale dzielnicowym dokonanym testamentem Krzywoustego, Płock utrzymał się jako stolica Mazowsza - księstwa dzielnicowego i był miejscem pochówku kolejnych książąt mazowieckich. Miasto było też siedzibą najwyższych władz kościelnych. W 1075 roku Bolesław Śmiały utworzył tu biskupstwo i ufundował pierwszą katedrę ${ }^{10}$. Zespół podlega nieustannie prowadzonym pracom konserwatorskim.

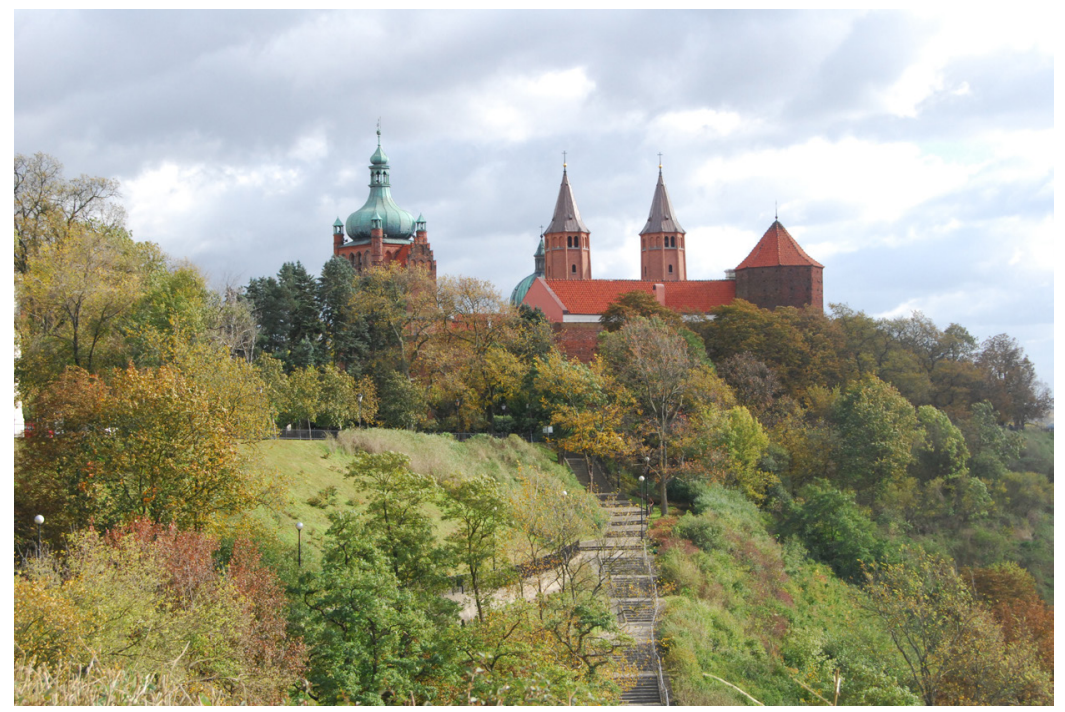

Fot. 2 Płock, Wzgórze Tumskie, stan w 2018 roku. Fot. J. Lewicki

- kolegiata pod wezwaniem Zwiastowania Najświętszej Maryi Panny w Pułtusku uznana za pomnik historii 10 grudnia 2018 roku $^{11}$. Jak podkreślono w uzasadnieniu, kolegiata jest zabytkiem o szczególnym znaczeniu dla dziedzictwa polskiego, jednym z najcenniejszych z epoki renesansu w Polsce. Należy do świątyń mazowieckich grupy pułtuskiej i jest jej najlepiej zachowanym przykładem. Szczególną wartość historyczną świątyni potwierdza fakt, że w podziemiach kościoła spoczywa zamożna szlachta i biskupi płoccy, o wybitnej wartości artystycznej świadczą natomiast oryginalne rozwiązania architektoniczne i bogaty wystrój malarski. Jej najbardziej

Rozporządzenie Prezydenta RP z dnia 20 kwietnia 2018 r. w sprawie uznania za pomnik historii „Płock Wzgórze Tumskie", Dz. U., 24 maja 2018, poz. 1003.

${ }_{10}$ https://www.nid.pl/pl/Informacje_ogolne/Zabytki_w_Polsce/Pomniki_historii/Lista_miejsc/miejsce. php?ID=3753, data wejścia $15 \mathrm{~V} 2019$.

${ }_{11}$ Rozporządzenie Prezydenta RP z dnia 10 grudnia 2018 r. w sprawie uznania za pomnik historii „Pułtusk - kolegiata pod wezwaniem Zwiastowania Najświętszej Maryi Panny”, Dz. U., 29 grudnia 2018, poz. 2462. 
charakterystycznym elementem jest oryginalne sklepienie kolebkowe o długości około $60 \mathrm{~m}$ ciągnące się przez całą długość nawy i prezbiterium pokryte dekoracją malarską, unikatową pod względem skali i programu treściowo-ideowego (Ryc.3). Jej dopełnieniem są renesansowe, iluzjonistyczne freski we wnętrzu kaplicy wybudowanej w latach 1553-1554 dla biskupa Andrzeja Noskowskiego. Szesnastowieczne polichromie zachowane na sklepieniu oraz w kaplicy są największym na ziemiach polskich i doskonale zachowanym zespołem renesansowych malowideł ${ }^{12}$. Kolegiata od szeregu lat jest przedmiotem prac konserwatorskich.

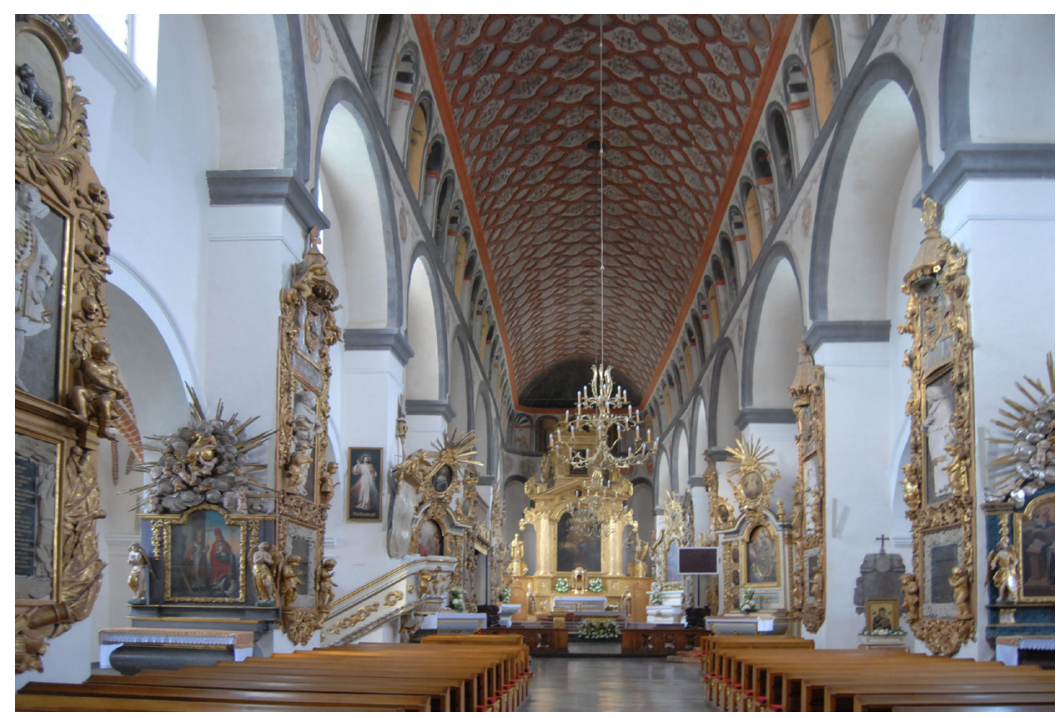

Fot. 3 Pułtusk, kolegiata pod wezwaniem Zwiastowania Najświętszej Maryi Panny, wnętrze, stan w 2013 roku. Fot. J. Lewicki

Liczba sześciu pomników historii na terenie Mazowsza jest jedną z mniejszych na terenie pozostałych województw. Mniej pomników historii posiada jedynie Województwo Podlaskie i Województwo Zachodniopomorskie. Stoi to w dużej sprzeczności z dużą liczbą zabytków na terenie Mazowsza, gdzie znajduje druga w Polsce, po województwie dolnośląskim liczba zabytków. Dużo więcej pomników historii znajduje się także w sąsiednich województwach: świętokrzyskim, łódzkim i małopolskim. Świadczy to o niedocenieniu rangi miejscowych zabytków i wskazuje na konieczność podjęcia intensywnych starań o uzyskanie statusu pomnika historii dla kolejnych wartościowych budowli na Mazowszu.

12 https://www.nid.pl/pl/Informacje_ogolne/Zabytki_w_Polsce/Pomniki_historii/Lista_miejsc/miejsce. php?ID=3934, data wejścia $15 \mathrm{~V} 2019$. 


\section{Jakub Lewicki}

\section{Pomniki Historii na Mazowszu - złożone wnioski}

Z chwilą objęcia stanowiska Mazowieckiego Wojewódzkiego Konserwatora Zabytków podjąłem starania na rzecz przygotowania wniosków uznania za pomnik historii wszystkich wyróżniających się zabytków z Mazowsza, które cechuje wysoka wartość zabytkowa. Złożone wnioski zostały przekazane do MKiDN. Są to:

- kościół ewangelicko-augsburski pw. Św. Trójcy w Warszawie. Wniosek z dnia 21 XI 2016 roku został złożony przez Parafię Ewangelicko-Augsburską Św. Trójcy w Warszawie. Wniosek przekazano do MKiDN 5 XII 2016 roku.

Kościół powstał w 4 ćwierci XVIII wieku. 15 stycznia 1777 ewangelicy otrzymali przywilej królewski zezwalający na budowę kościoła, a król Stanisław August Poniatowski osobiście wybrał projekt Szymona Bogumiła Zuga, który został zrealizowany. Inspiracją dla architekta Szymona Bogumiła Zuga był rzymski Panteon oraz kościół Najświętszej Marii Panny w Dreźnie ${ }^{13}$. Mimo zniszczeń wojennych i powojennej odbudowy kościół zachował bryłę i wszystkie wartościowe elementy wystroju. Mimo z pozoru dobrego stanu, budowla wymaga prac konserwatorskich. Konieczny jest remont kopuły i innych elementów wnętrza.

- zamek książąt mazowieckich w Czersku. Wniosek z 1 IX 2017 roku przekazano do MKiDN 21 XI 2017 roku.

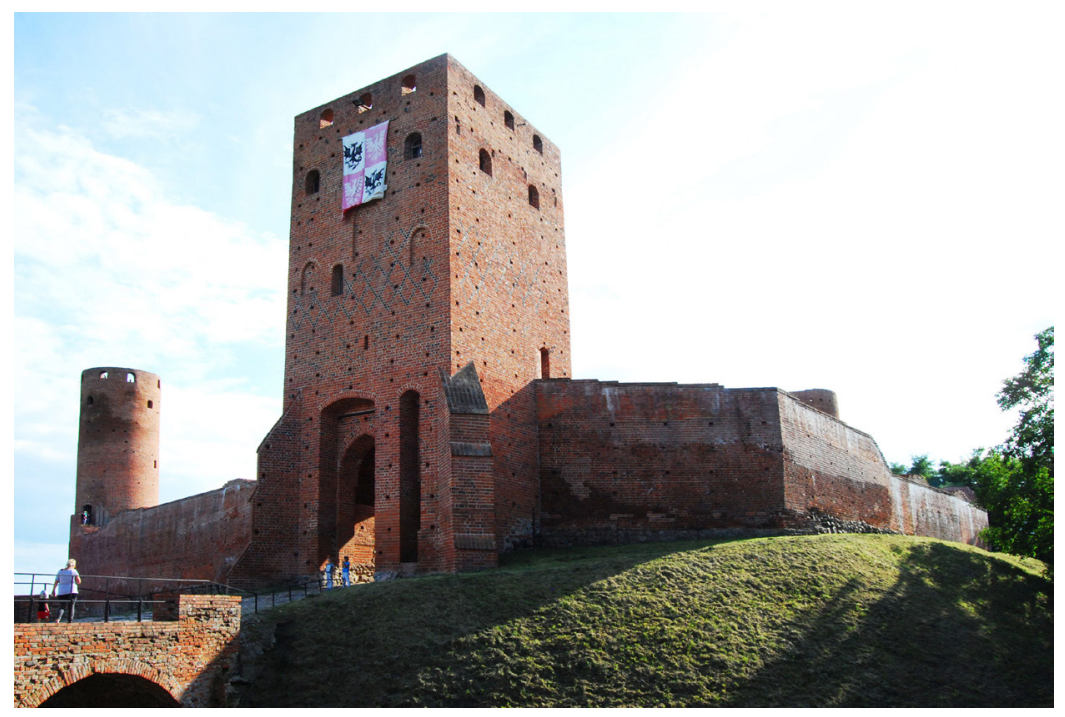

Fot. 4 Czersk, zamek książąt mazowieckich, widok ogólny, stan w 2018 roku. Fot. J. Lewicki

Zamek znajduje się w południowej części województwa. Ruiny wpisane są do rejestru zabytków decyzją z dn. 25.01.1958 roku (nr rejestru A-1009/116). Do dzisiaj czytelne są dwie cylindryczne wieże (południowa i zachodnia), wieża bramna (Ryc. 4), północne i zachodnie mury zamkowe 
oraz fragmenty zabudowy dziedzińca. Zamek powstał na przełomie XIV i XV wieku ${ }^{14}$.Zamek był kilkakrotnie przebudowywany. Jeszcze po połowie XVIII wieku dokonywano jego napraw (1762). W 1904 roku ruiny zamku zostały przekazane na własność Towarzystwu Opieki nad Zabytkami Przeszłości. W latach 1907-1911 TOnZP przeprowadziło prace konserwatorskie na zamku, którymi kierował architekt i konserwator Kazimierz Skórewicz. Ich celem było zabezpieczenie murów budowli. W okresie międzywojennym w 1927 roku Antoni Karczewski przeprowadził badania archeologiczne, a architekt Jan Łukasik kierował pracami konserwatorskimi przy wieży bramnej. Kolejne badania kilkakrotnie prowadzono w okresie międzywojennym, które już na początku lat $60 \mathrm{XX}$ wieku pozwoliły ustalić chronologię zabytku. Wówczas też kilkakrotnie przeprowadzono prace zabezpieczające mury, jak i nową cegłą przelicowano fragmenty ścian $^{15}$. W 2011 roku przeprowadzono remont drogi prowadzącej na zamek. W 2012 i 2013 roku przeprowadzono konserwację murów zamku oraz wieży południowej i zachodniej. Zamek pozostaje $\mathrm{w}$ formie trwałej ruiny udostępnionej do zwiedzania. W najbliższych latach konieczne są duże prace zabezpieczające i wzmacniające mury. Ruiny zamku wymagają prac, które zabezpieczą mury budowli i które ostatecznie ukształtują jego udostępnienie i ekspozycję ruin nie naruszając substancji zabytkowej. Niewątpliwie będzie to wymagało szczegółowego nadzoru MWKZ.

- zespół pobenedyktyński w Opactwie koło Sieciechowa. Wniosek z dnia 29 IX 2017 roku złożony przez Starostwo Powiatowe w Kozienicach i Parafię Wniebowzięcia NMP w Opactwie przekazano do MKiDN.

Opactwo benedyktyńskie ufundował w 2. poł. XI wieku król Bolesław II Śmiały. W latach 1739-1748 i 1749-1767 i później do 1770 przeprowadzono przebudowę i odbudowę kościoła i klasztoru ${ }^{16}$. Wykonano też polichromię wnętrz kościoła. Dekoracja obejmuje kompletną artykulację wnętrza $\mathrm{z}$ dekoracjami sklepień i poza wątkami religijno-moralnymi

\footnotetext{
14 Karczewski A., Czersk, Warszawa 1939; Zagrodzki T., Czersk. Zamek i miasto historyczne, Warszawa 1988, s. 128-135; Guerquin B., Zamki w Polsce, Warszawa 1984, s. 132-134; Architektura gotycka w Polsce, red. T. Mroczko i M. Arszyński, Warszawa 1995, T. 2, Katalog zabytków, s. 51-52, 304, 371; Kajzer T. L., Kołodziejski S., Salm J., Leksykon zamków w Polsce, red. nauk L. Kajzer, Warszawa 2012, s. 140-143; Czersk Wzgórze Zamkowe Badania 1974-1983, P. Urbańczyk (red.), Warszawa 2016.

15 Opis prac według sprawozdań i dokumentacji konserwatorskich z Archiwum Wojewódzkiego Urzędu Ochrony Zabytków w Warszawie.

16 Gacki J., Benedyktyński klasztor w Sieciechowie według pism i podań miejscowych przez..., Radom 1872; Wiśniowski E., Z dziejów opactwa benedyktyńskiego w Sieciechowie (XIII-XVII w.), „Roczniki Humanistyczne KUL", t. 7: 1958, z. 2, Lublin 1960, s. 23-120; Brykowska M., W sprawie architektury zespołu pobenedyktyńskiego w Opactwie-Sieciechowie, „Kwartalnik Architektury i Urbanistyki”, XV: 1970, z. 2, s. 203-211; Miszczak D., Późnobarokowy kościót pobenedyktyński w Sieciechowie-Opactwie, „Rocznik Muzeum Świętokrzyskiego”, IX: 1975, s. 367-383; Wojciechowski A., Sieciechów - studium historyczno-urbanistyczne, PKZ Lublin 1982, mps; Zdon W., Świątynia jako miejsce na granicy przemijania i wiecznej szczęśliwości, czyli o znaczeniu campanulli w architekturze kościoła opackiego w Sieciechowie, [w:] Obraz i przyroda, red. M. Mazurczak, J. Patyra, M. Żak, Lublin 2005, s. 549-559; Zdon W., Dydaktyka zbawienia na sklepieniach pobenedyktyńskiego kościoła w opactwie sieciechowskim, „Arteria - Rocznik Katedry Sztuki Wydziału Nauczycielskiego Politechniki Radomskiej” 2008, nr 6, s. 33-38.
} 
i dydaktycznymi przeznaczonymi dla wspólnoty klasztornej, zawiera rozbudowany program historyczny. Dekoracja malarska powstała w kilku fazach: rokokowej (ołtarz główny i ściana tarczowa fasady $z$ datą 1770) i wczesnoklasycystycznej (sklepienia i ściany boczne wnętrza, parapet chóru muzycznego z datą 1779). Autorem drugiej fazy był prawdopodobnie Szymon Mańkowski (ok. 1724-1788) pracujący w następnych latach głównie jako malarz-dekorator dla króla w Łazienkach i dla elity magnackiej w jej stołecznych rezydencjach ${ }^{17}$, brak natomiast danych o autorze fazy rokokowej. Malowidła przechodziły kompleksowe restauracje w 1926 roku i w latach 1943-1946. Wokół kościoła znajdują się zachowane resztki zabudowy klasztornej. Kościół i pozostałości klasztoru będą wymagały kompleksowych prac konserwatorskich (Ryc. 5).

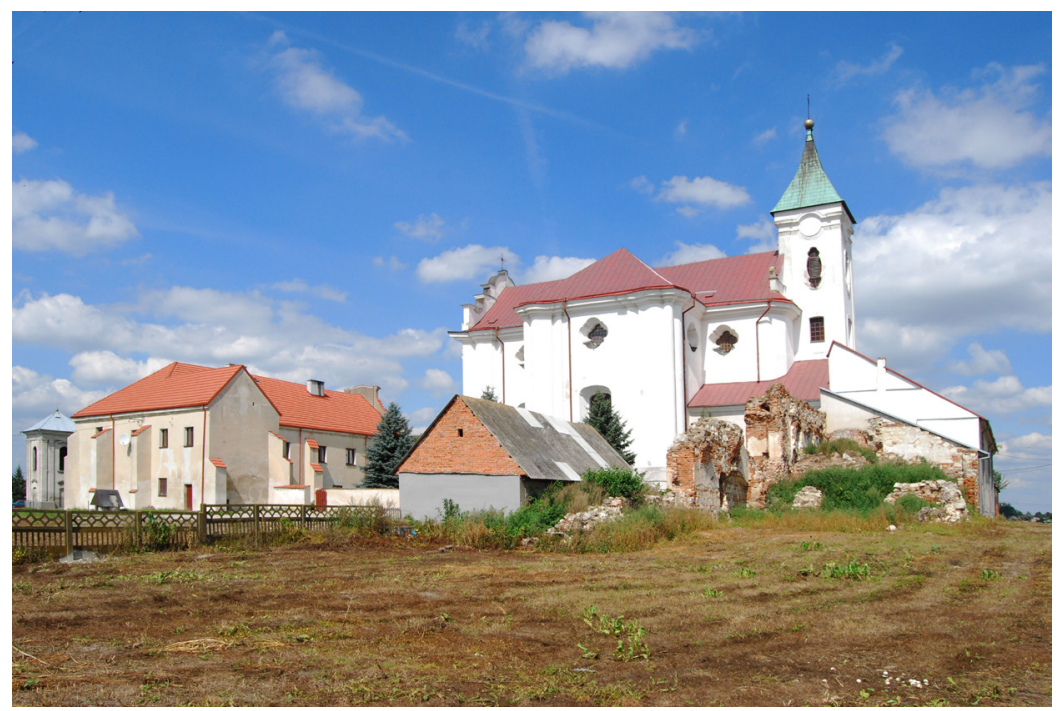

Fot. 5 Sieciechów Opactwo, zespół pobenedyktyński, widok ogólny, stan w 2016 roku. Fot. J. Lewicki

- kościół parafialny pw. Św. Jana Chrzciciela i Podwyższenia Krzyża w Krasnem. Wniosek z dnia 19 I 2018 roku został złożony przez parafię rzymskokatolicką p.w. Św. Jana Chrzciciela w Krasnem i przekazano do MKiDN.

Krasne było miejscowością rodową Krasińskich herbu Korwin/Ślepowron. Murowany kościół w obecnej formie powstał dopiero w latach 1739-1746 lub w 1749 roku z inicjatywy ówczesnego właściciela Błażeja Jana Krasińskiego, starosty opinogórskiego prawdopodobnie wg projektu warszawskiego architekta Jakuba Fontany $(1710-1773)^{18}$ (Ryc. 6). Wówczas pod kierunkiem budowniczego Marcina Wiśniewskiego wzniesiono nowy korpus nawowy artykułowany pilastrami toskańskimi i sklepiony kolebkowo-krzyżowo z lunetami oraz okazałą zakrystię ze

\footnotetext{
17 Prószyńska Z., Mańkowski Szymon, [w:] Słownik artystów polskich i obcych w Polsce działajacych. Malarze - rzeźbiarze - graficy, t. 5, po red. J. Derwojeda, Warszawa 1993, s. 338-340.

18 Gawarecki W. H., Opis kościoła w Krasnem, i w nim będących nagrobków familii Krasińskich, [w:] idem, Pamiętnik Historyczny Płocki, t. II, 1830, s. 100-139; Dzierzwicki P., Bieniewska B., Liczbiński A., Prace konserwatorskie w województwie warszawskim w latach 1953-1954, „Ochrona Zabytków”, 8: 1955, z. 1, s. 62.
} 
skarbcem na piętrze. Wnętrze zdobi dekoracja malarska Sebastiana Ecksteina malarza-freskanta z Brna, który wymalował w technice mieszanej podziały architektoniczne ścian i sklepień, a także wielki cykl 11 malowideł związanych z historią Krzyża Św. w nawie głównej i iluzjonistyczne ołtarze w nawach bocznych ${ }^{19}$. We wnętrzu znajduje się kilka XVII-wiecznych płyt epitafijnych umieszczonych na filarach międzynawowych, a także pomniki Krasińskich - m. in. epitafium Jakuba Krasińskiego (zm. 1737, wyk. 1747) i Marianny z Czarnowskich (zm. 1745). Kościół był odnawiany i modernizowany od 1870 roku, a potem konserwowany w latach 1956-1957 przez zespół prof. Karola Dąbrowskiego z ASP w Warszawie. Od 2010 roku grupa pod kierunkiem prof. Pawła Marka Jakubowskiego z ASP w Warszawie kontynuuje prace konserwatorskie. Po 17 latach pracy, zakonserwowano $40 \%$ zachowanych fresków i przygotowano wytyczne do odsłonięcia i restauracji kolejnych ich partii. Zakończenie prac przewidywane jest na rok 2021.

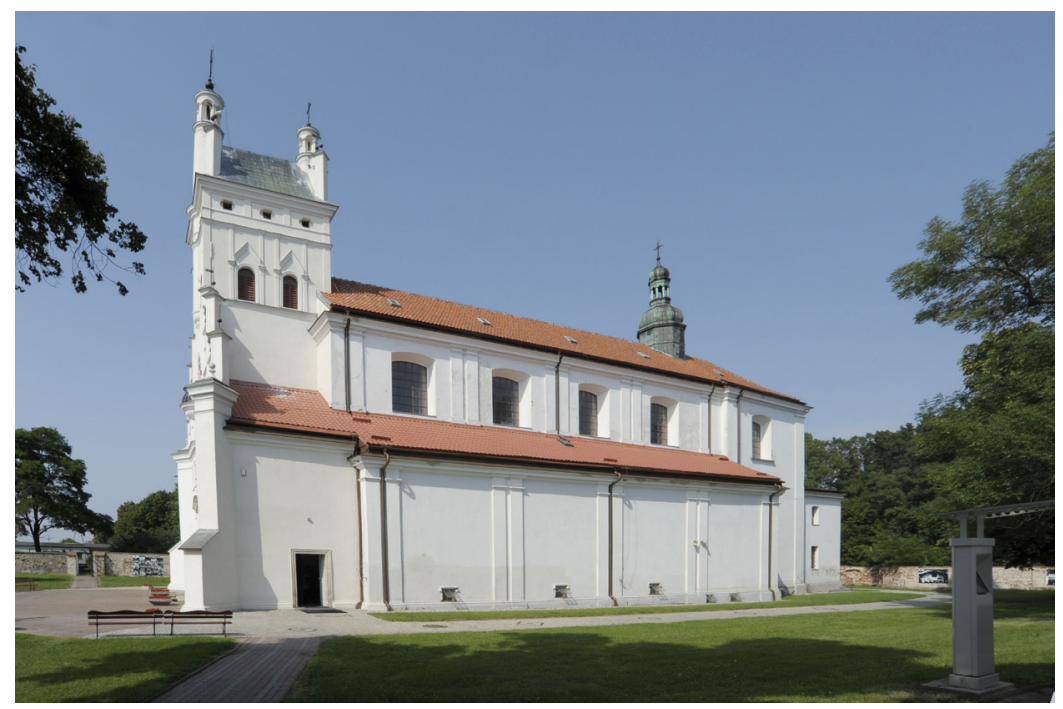

Fot. 6 Krasne, kościół parafialny pw. Św. Jana Chrzciciela i Podwyższenia Krzyża, stan w 2018 roku. Fot. J. Lewicki

- bazylika św. Jana Chrzciciela w Brochowie (Ryc. 7). Wniosek z 8 III 2018 roku przesłany został od razu do Kancelarii Prezydenta RP, co stanowiło naruszenie dotychczasowej procedury. Do delegatury w Płocku wpłynęła jedynie kopia wniosku, nie złożono żadnych dokumentów w urzędzie Mazowieckiego Wojewódzkiego Konserwatora Zabytków w Warszawie. Kościół o charakterze obronnym w stylu gotycko-renesansowym w obecnej formie powstał w latach 1551-1561, a autorem przebudowy był Jan Baptysta z Wenecji (Ryc. 7). Świątynię przebudowano $\mathrm{m}$. in. po 1655 roku i odbudowano po I wojnie światowej. Gruntownie rementowana w latach 2008-10 i wówczas zrekonstruowano renesansowe polichromie sklepienia. 


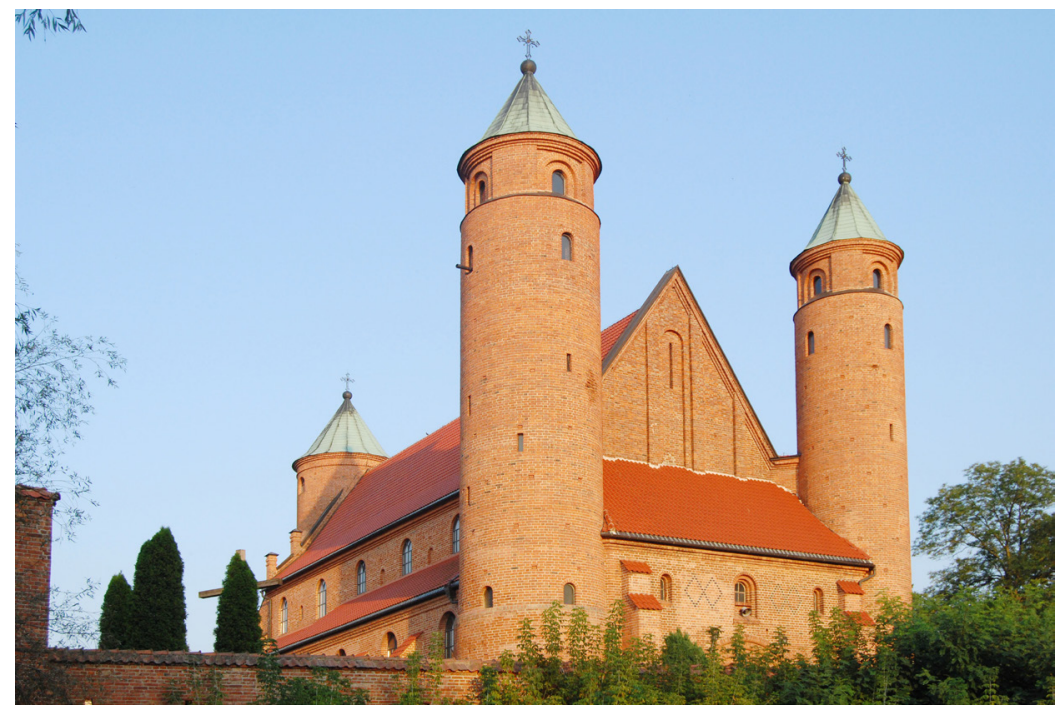

Fot. 7 Brochów, bazylika św. Jana Chrzciciela, stan w 2016 roku. Fot. J. Lewicki

- willa „Milusin”, ul. Oleandrów 5 w Sulejówku. Wniosek z dnia 22 VI 2018 roku został złożony przez Muzeum Józefa Piłsudskiego w Sulejówku. Wniosek przekazano do MKiDN 6 VIII 2018 roku. Dworek „Milusin” zaprojektował Kazimierz Skórewicz. Był to dom dla rodziny Piłsudskich, zakupiony ze składek żołnierzy polskich dla Marszałka. W sąsiedztwie dworku „Milusin” powstaje nowoczesny budynek muzealno-edukacyjny łączący $\mathrm{w}$ sobie funkcje wystawiennicze, edukacyjne i animacyjne. Częścią muzeum będzie także dawny ogród.

- Bank Gospodarstwa Krajowego, Al. Jerozolimskie 7 w Warszawie. Wniosek z dnia 11 XII 2018 roku został wykonany przez Departament Logistyki i Administracji BGK. Wniosek przekazano do MKiDN 20 II 2019 roku.

Budynek banku został wzniesiony w latach 1928-1931 według projektu Rudolfa Świerczyńskiego dla Banku Gospodarstwa Krajowego. Został ozdobiony płaskorzeźbami Jana Szczepkowskiego. Przy wystroju plastycznym wnętrz współpracowali m. in. Wojciech Jastrzębowski (witraże) oraz Felicjan Szczęsny Kowarski, Wacław Borowski i Romuald Kamil Witkowski (malarstwo). Budynek nie został zniszczony w czasie II wojny światowej. Planowany jest kompleksowy remont wnętrz $\mathrm{z}$ oryginalnym wystrojem, co będzie wymagało szczegółowego nadzoru konserwatorskiego.

- opactwo romańskie w Czerwińsku nad Wisłą, ul. Klasztorna 23. Wniosek z dnia 6 III 2019 roku został złożony przez parafię rzymskokatolicką Bazyliki Zwiastowania N.M.P. Wniosek przekazano do MKiDN 10 IV 2019 roku.

Dawne opactwo kanoników regularnych laterańskich w Czerwińsku nad Wisłą jest największym założeniem klasztornym na historycznym Mazowszu (Ryc. 8). Kościół klasztorny wzniesiony został przed 1155 rokiem, przekształcony częściowo w 1 poł. XIII w., przebudowany po roku 1328, XIV/XV w., ok. 1500 i przed 1538 oraz 1630-1633, remontowany przed 1765 
i w latach $1768-1775^{20}$. Prace restauracyjne prowadzono pod kierunkiem arch. Stefana Szyllera z inicjatywy TOnZP. Jest najcenniejszą romańską budowlą na Mazowszu, a także największym zespołem malarstwa monumentalnego $z$ epoki średniowiecza i nowożytnej. We wnętrzach romańsko-gotycko-wczesnobarokowego kościoła konwentualnego p. w. Zwiastowania Najśw. Maryi Panny oraz dawnego kapitularza opackiego i dolnej sali w reprezentacyjnym skrzydle wschodnim zwanym pałacem opatów zachowały się malatury al fresco i al secco pochodzące aż $\mathrm{z}$ dwunastu różnych warstw historycznych od XII do 2. poł. XVIII w. Kościół i klasztor wciąż wymaga kompleksowych prac konserwatorskich.

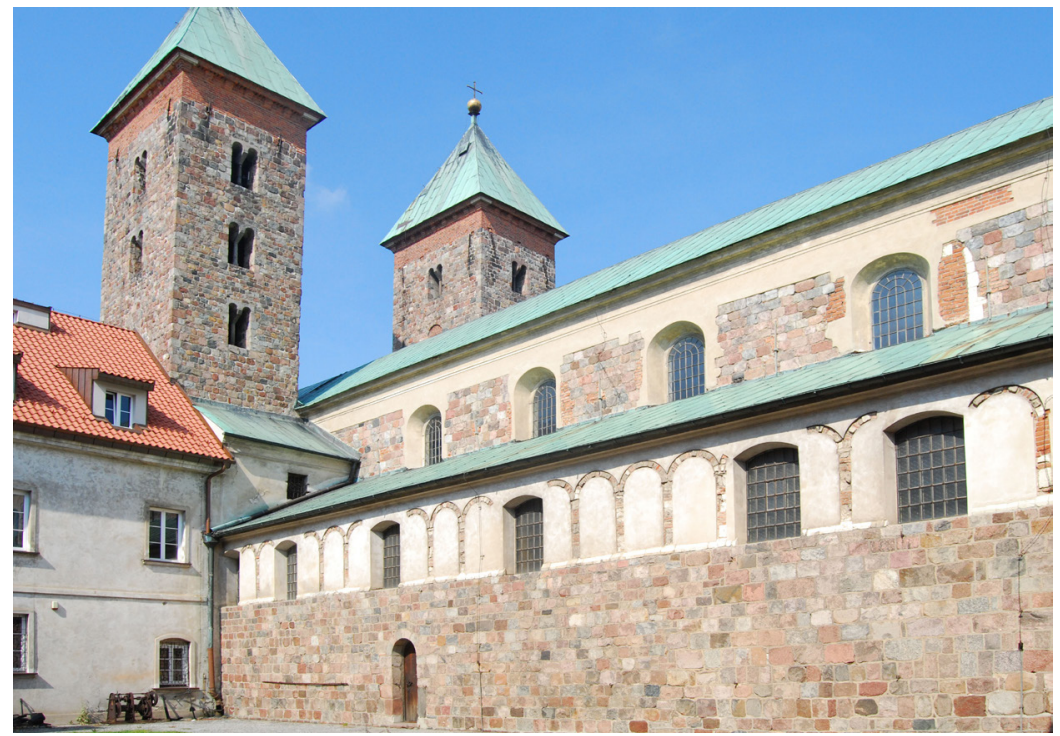

Fot. 8 Czerwińsk nad Wisłą, kościół klasztorny, widok od strony dziedzińca, stan w 2016 roku. Fot. J. Lewicki

- dzielnica Żoliborz. Wniosek przesłany został do MKiDN z pominięciem Urzędu Mazowieckiego Wojewódzkiego Konserwatora Zabytków, co stanowiło naruszenie dotychczasowej procedury.

- pomnik - Cmentarz Bohaterów Powstania Warszawskiego. Żoliborz. Wniosek przesłany został do MKiDN z pominięciem Urzędu Mazowieckiego Wojewódzkiego Konserwatora Zabytków, co stanowiło naruszenie dotychczasowej procedury.

${ }_{20}$ Dąbrowski K., Konserwacja malowideł ściennych w Czerwińsku: odkrycie romańskiej polichromii, „Ochrona Zabytków”, 4: 1951, nr 3-4, s. 127-132; Świechowski Z., Ścienne malowidła romańskie w Czerwińsku, „Biuletyn Historii Sztuki”, 15: 1953, nr 2, s. 64-74; Dąbrowski K., Problemy konserwatorskie romańskiej polichromii w Czerwińsku, „Biuletyn Historii Sztuki”, 15: 1953, nr 2, s. 75-76; Bieniewska B., Liczbiński A., Prace konserwatorskie w województwie warszawskim w latach 1953-1954, „Ochrona Zabytków”, 8: 1955, z. 1, s. 57-62; Bieniewska B., Zakres i problematyka prac konserwatorskich (1945-1958), „Biuletyn Konserwatorski Województwa Warszawskiego", Warszawa 1958, s. 7-64; Mroczko T., Czerwińsk romański, Warszawa 1972; Stawski M., Opactwo czerwińskie w średniowieczu. Opactwo kanoników regularnych w Czerwińsku w średniowieczu, Warszawa 2007; Omilanowska M., Architekt Stefan Szyller 1857-1933, Warszawa 2008; Nowiński J., Czerwińsk, Warszawa 2012. 
Nie wszystkie wnioski były wykonane na odpowiednim poziome. Niektóre z nich zawierały błędy świadczące o nieprofesjonalnym wykonaniu. Mylono daty powstania budowli, ich styl, a nawet podawano nieprawidłowe podstawowe nazwy z historii sztuki, mimo że najważniejszym kryterium uznania za pomnik historii miały być wartości artystyczne zabytku.

Ponadto do urzędu Mazowieckiego Wojewódzkiego Konserwatora Zabytków wpłynęły inne dokumenty lub niekompletne wnioski. Były to:

- zespół bernardyński w Radomiu. Wniosek z 9 II 2018 roku miał zostać poprawiony, co wykonano.

Fundowany w 1468 roku zespół jest jednym z najlepiej zachowanych kompleksów klasztornych w Polsce. Murowany kościół i klasztor zostały wzniesione w kilku fazach ${ }^{21}$. Bernardyni sami wybudowali cegielnię, w której wypalali gotyckie cegły. W pierwszej kolejności wybudowane zostało prezbiterium wraz z zakrystią, która miała pełnić funkcję skarbca (w chwili obecnej kaplica Matki Boskiej Anielskiej). Następnie wzniesione zostało południowe skrzydło klasztorne. Kolejnym etapem był korpus kościoła wybudowany pod koniec XV wieku. Najpóźniej wzniesione zostały pozostałe skrzydła klasztorne połączone krytym piętrowym krużgankiem z niewysoką wieżyczką w północno-wschodnim narożniku charakterystyczną dla średniowiecznych klasztorów bernardynów. Kościół rozbudowywano i przebudowano po 1506 r., przed 1602, 1630-1633. Świątynię zregotycyzowano w latach 1911-1914 pod kierunkiem Stefana Szyllera ${ }^{22}$ (Ryc. 9). Od szeregu lat jest przedmiotem kompleksowych prac konserwatorskich.

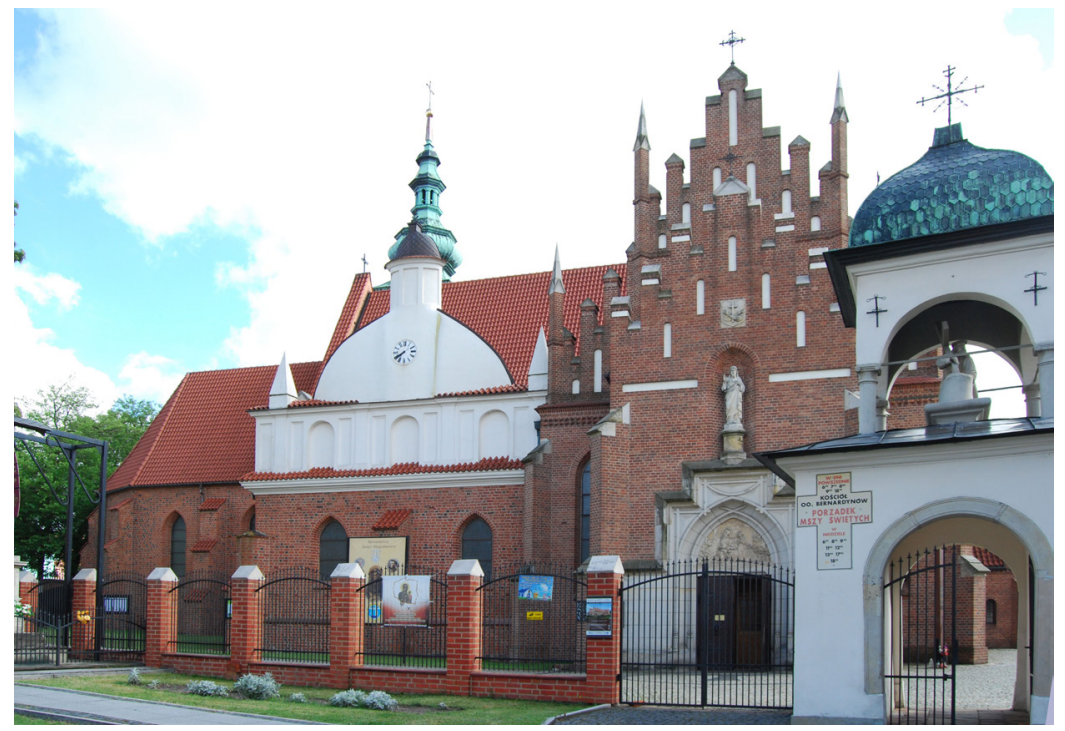

Fot. 9 Radom, zespół kościoła i klasztoru bernardynów, stan w 2016 roku. Fot. J. Lewicki

$21 \quad$ Luboński J., Monografia historyczna miasta Radomia, Radom 1907, s. 122-130; Wiśniewski J., Dekanat Radomski, Radom 1911, s. 237-368; Katalog zabytków sztuki w Polsce, Tom III, Województwo Kieleckie, zeszyt 10, powiat radomski, Warszawa 1961.

22 Efrem A. Obruśnik OFM, Zespół kościoła i klasztoru Ojców Bernardynów w Radomiu, „Biuletyn Kwartalny Radomskiego Towarzystwa Naukowego", XXXIX: 2004, z. 1-4, s. 109-128; Krawczyk M., Stan W., Bernardyni radomscy. Zarys dziejów, Radom 2013. 
- Węgrów, zespół kościoła i klasztoru reformatów. Jest to najlepiej zachowany zespół zabytkowy w Węgrowie i dlatego też namówiłem do złożenia odpowiednich dokumentów. Wniosek został złożony przez parafię rzymskokatolicką p. w. Św. Piotra i Pawła w Węgrowie. Wpłynęła wstępna wersja dokumentu, a pismem z dnia 24.10.2018 przesłano uwagi do wniosku, który miał zostać poprawiony.

Okazały murowany kościół konwentualny franciszkanów - reformatów w Węgrowie Jan Dobrogost Krasiński wzniósł w latach 1693-1706 ${ }^{23}$. Projekt kościoła wykonali Tylman van Gameren i Carlo Ceroni (Ryc. 10). Malowidła wewnątrz wykonał w latach 1707-1711 Michelangelo Palloni i zachowały się one w bardzo dobrym stanie, w przeciwieństwie do kościoła farnego, gdzie zostały znacząco przemalowane. Także w krużgankach klasztornych odkryto przemalowane malowidła ścienne, które wymagają odsłonięcia i konserwacji. W kościele są prowadzone prace remontowe i konserwatorskie, jeszcze szerszy zakres prac $\mathrm{w}$ najbliższych latach obejmie klasztor i jego wystrój.

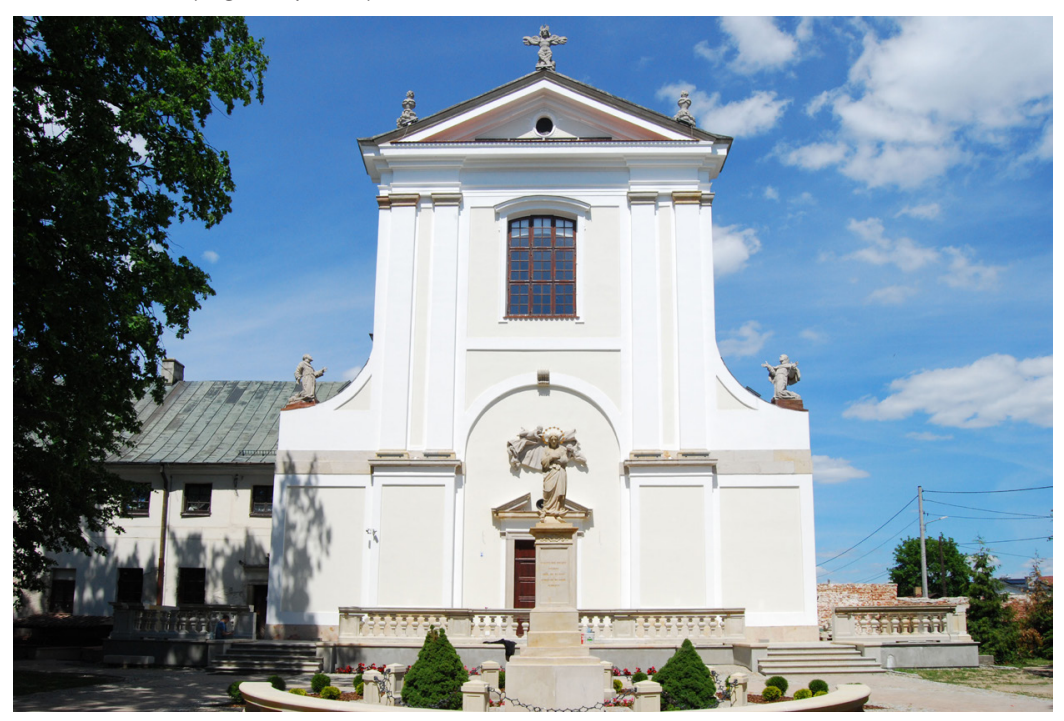

Fot. 10 Węgrów, kościół i klasztor reformatów, stan w 2016 roku. Fot. J. Lewicki

Ponadto skierowano pisma do właściciela kościoła w Mariańskim Porzeczu i do właściciela zespołu osadniczego w Podebłociu zachęcające do złożenia wniosków o nadanie statusu pomnika historii.

\footnotetext{
23 Karpowicz M., Działalność artystyczna Michelangela Palloniego w Polsce, Warszawa 1967; Karpowicz M., Sztuka oświeconego sarmatyzmu, Warszawa 1986; Karpowicz M., Sztuka Warszawy czasów Jana III, Warszawa 1987; Węrów: dzieje miasta i okolic w latach 1441-1944: praca zbiorowa, pod red. A. Kołodziejczyka i T. Swata, Towarzystwo Miłośników Ziemi Węgrowskiej, Węgrów 1991; Karpowicz M., Cuda Węgrowa, Węgrów 2009; Słowiński K., Bogu i ludziom: parafia i kościót p.w. Wniebowzięcia Najświętszej Marii Panny w Wegrowie w XVXXI wieku, Radom 2011.
} 


\section{Propozycje nowych pomników historii na Mazowszu}

W związku z wieloletnimi zaniedbaniami dotyczącymi składanych wniosków uznania za pomnik historii podjęto starania w sprawie przygotowania odpowiednich dokumentów. W mojej ocenie na status pomnika historii zasługują:

1. Iłża, zamek i miasto.

Przeprowadziłem rozmowy z Burmistrzem Miasta Przemysławem Burkiem w sprawie przygotowania odpowiedniego wniosku. Uważam, że jest to jeden z najcenniejszych zespołów zabytkowych na terenie Mazowsza. Za pomnik historii powinien zostać uznany zamek, jak i najważniejsze budowle miasta w obrębie murów obronnych.

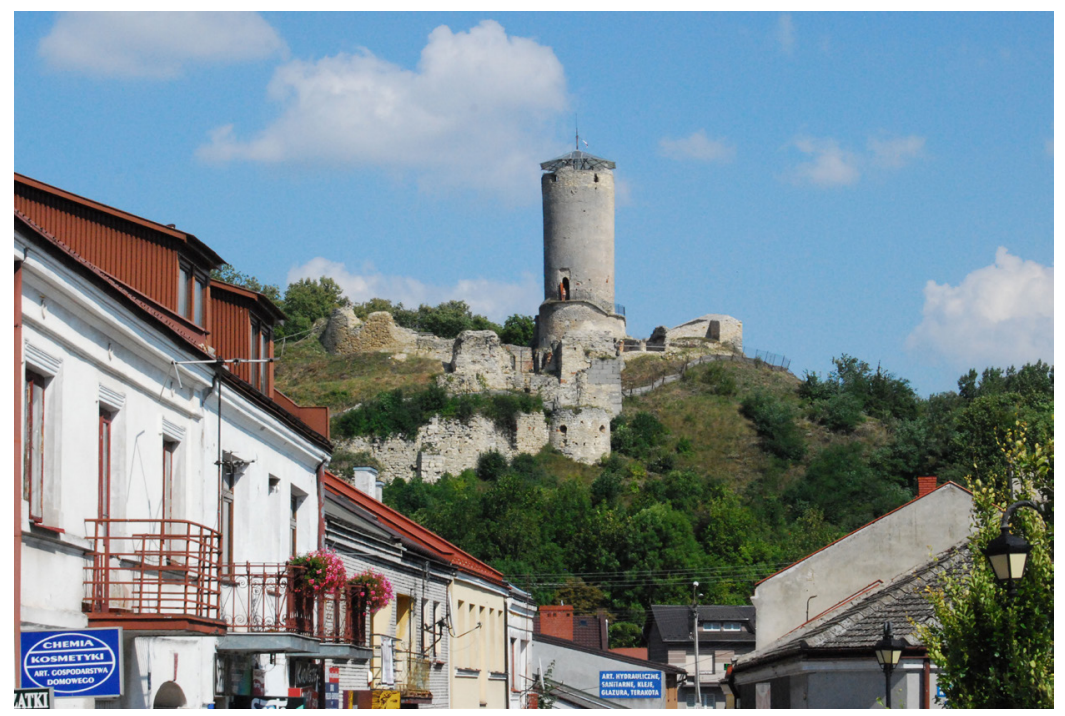

Fot. 11 Iłża, zamek i miasto, stan w 2018 roku. Fot. J. Lewicki

Iłża w okresie staropolskim była ośrodkiem administracyjnym i miejscem częstego pobytu biskupów krakowskich ${ }^{24}$. Na górującym nad miastem wzgórzu zbudowano zamek, a fundatorem był biskup Jan Grot (ok. 1340) (Ryc. 11). Zamek często gościł kolejnych biskupów krakowskich i wielokrotnie był przebudowywany. Budowla składała się z wieży głównej i nieregularnej zabudowy mieszkalnej, która przylegała do średniowiecznego obwodu warownego. Tam też ulokowano pomieszczenia reprezentacyjno-mieszkalne. Poniżej znajdowały się zabudowania gospodarcze otoczone nowożytnymi fortyfikacjami, które tworzyły zamek niski. Liczne przebudowy zamku i jego wnętrz nastąpily w 2 połowie XVII i w XVIII wieku. W 1909 r. teren zamku został przekazany Towarzystwu Opieki nad Zabytkami Przeszłości, które od tej chwili

${ }^{24}$ Lewicki J., Dzieje i architektura zamku w Iłży. Problematyka badawcza i konserwatorska [w:] Siedziby biskupów krakowskich na terenie dawnego Województwa sandomierskiego, red. L. Kajzer, Kielce 1997, s. 57-83; $Z$ dziejów budownictwa rezydencjonalno-obronnego na ziemi iłżeckiej, red. D. Kalina, R. Kubicki, Kielce-Iłża 2011; Nowakowski P., Itża miasto kościelne, Radom 2012; Miasto w nowej odsłonie. Monografia Iłży, t. 1, Od czasów najdawniejszych do 1945 roku, pod red. S. Piątkowskiego, Warszawa 2014. 
prowadziło prace konserwatorskie. Wykonano wówczas pierwszą inwentaryzację ruin (rysunki murów, fotografie). Od 1969 roku przez szereg kolejnych lat (1969-1978) kompleksowe badania archeologiczno-historyczne prowadził zespół architektów z Politechniki Wrocławskiej. Ich efektem było wykonanie częściowo zrealizowanych projektów zabezpieczenia ruin zamkowych. Kilkakrotnie odgruzowano ruiny zamku górnego, zabezpieczano też koronę murów. Badania i prace konserwatorskie prowadzono intensywnie w ostatnich latach. Zamek znajduje się w południowej części województwa. Ruiny wpisane są do rejestru zabytków decyzją z dn. 24.03.1947 roku (nr rejestru A-23), decyzją z dn. 23.06.1967 (nr rejestru A- 156) oraz decyzją z dn. 18.03.1981 ( $\mathrm{nr}$ rejestru A-96). Dodatkowo w rejestrze zabytków znajduje się park na wzgórzu zamkowym (decyzja z dn. 24.03.1947, nr rej. A-23).

Duże wartości zabytkowe ma miejscowy kościół farny p.w. Wniebowzięcia Najświętszej Maryi Panny wraz z kaplicą mauzoleum rodziny Szyszkowskich z lat 1629-1630 z dekoracją Macieja Reichana. Ponadlokalne wartości zabytkowe mają także wybrane fragmenty zabudowy miejskiej. Cały zespół wymaga kompleksowych prac konserwatorskich.

2. Szydłowiec, zamek i miasto.

Uważam, że jest to jeden z najcenniejszych zespołów zabytkowych na terenie Mazowsza. Bardzo wysoką wartość posiada kościół i zamek Szydłowieckich. Za pomnik historii powinien zostać uznany kościół parafialny, zamek, jak i najważniejsze budowle miasta oraz cmentarz żydowski.

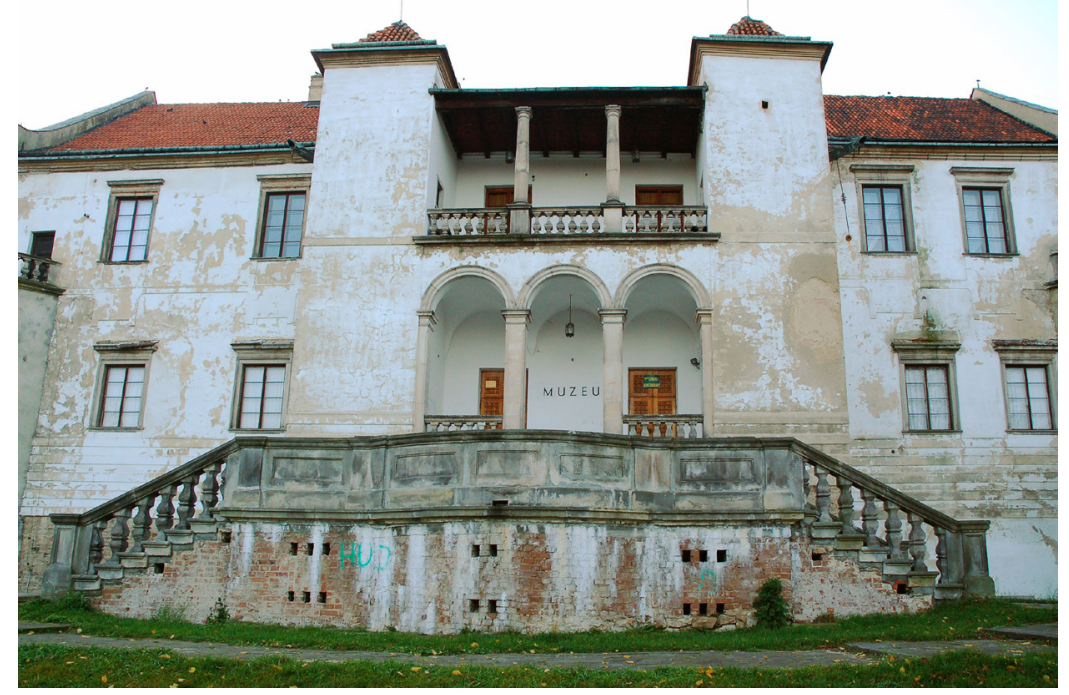

Fot. 12 Szydłowiec, zamek, widok ogólny, stan w 2007. Fot. J. Lewicki

Zamek w Szydłowcu wraz z ogrodem zamkowym i fosą ${ }^{25}$, obecnie pełniący funkcję muzeum i domu kultury wpisany jest do rejestru zabytków decyzją z dn. 11.02.1947 (nr rejestru 19/A/47, decyzją z dn. 23.06.1967 r.) oraz decyzją z dn. 18.03.1982 roku (nr rej. 394). Położony

25 Guerquin B., Zamki w Polsce, Warszawa 1984, s. 298-300; Kajzer L., Kołodziejski S., Salm J., Leksykon zamków w Polsce, red. nauk L. Kajzer, Warszawa 2012, s. 483-487. 
na wyspie nizinny zamek został wzniesiony w latach 1470-1480 na miejscu grodu, przez kasztelana żarnowskiego i radomskiego Stanisława Szydłowieckiego. Za sprawą jego prawnuka, podskarbiego wielkiego koronnego Mikołaja Szydłowieckiego, budowlę przebudowano w latach 1515-1526 w okazałą renesansową rezydencję o cechach obronnych. Dalsze prace modernizacyjne prowadzili kolejni ordynaci nieświescy książęta Krzysztof Mikołaj „Sierotka” i Albrecht Stanisław Radziwiłłowie w latach 1609-1610 i 1619-162926. Po zaniedbaniach w XIX wieku i próbach zapobieżenia powolnej rujnacji zamku w 1. połowie XX wieku wykonano w latach 1950-1952 jego pierwszy remont, a potem w latach 60 i 70 XX wieku i w latach 20132015 kolejne. Zamek został całkowicie odbudowany (Ryc. 12). Zrekonstruowano fragmenty budowli uzupełniając je współczesnymi elementami. Zachowano jednak historyczną sylwetę budowli. Zamek pełni współczesne funkcje - domu kultury i muzeum. Zamek w Szydłowcu był w latach 2013-2015 przedmiotem kompleksowych prac remontowych i konserwatorskich, które utrzymały wcześniejszą koncepcję architektoniczną wprowadzając do niej niewielkie zmiany.

Farę miejską wzniesiono w dwóch fazach od 1493 do 1509 roku z fundacji Jakuba Szydłowieckiego oraz w latach 1515-1532. Ponadlokalne wartości zabytkowe mają także wybrane fragmenty zabudowy miejskiej i cmentarz żydowski. Cały zespół zabudowy miejskiej wymaga kompleksowych prac konserwatorskich, zamek i kościół znajdują się w dobrym stanie.

3. Warszawa, Budynek MWRiOP, Al. Szucha.

Gmach jest jednym z zabytków o bardzo wysokiej wartości historycznej, artystycznej i naukowej na terenie Warszawy. Powinien on zostać uznany za pomnik historii.

Budynek zaprojektował Zdzisław Mączeński. Budowę gmachu rozpoczęto w 1927 roku. Był on jedną z pierwszych zbudowanych od podstaw siedzib ministerialnych w II Rzeczypospolitej. Gmach powstał w niespełna 3 lata i charakteryzował się klasycyzującymi formami. W 1928 odbył się konkurs na projekt wnętrz. Wygrał go Wojciech Jastrzębowski profesor warszawskiej Szkoły Sztuk Pięknych i równocześnie dyrektor Departamentu Sztuki w MWRiOP. Podczas II wojny światowej gmach był miejscem przesłuchiwania, męczeństwa i śmierci wielu Polaków. Budynek jest pieczołowicie chroniony, a wystrój konserwowany.

\section{Porzecze Mariańskie, kościół drewniany.}

Uważam, że jest to jeden z najcenniejszych zabytkowych kościołów drewnianych na terenie Mazowsza, który powinien zostać uznany za pomnik historii.

W miejscowym kościele należącym w latach 1699-1864 i ponownie od 1966 roku do zgromadzenia księży marianów, służącym jednocześnie jako sanktuarium cudownego obrazu Matki Bożej Częstochowskiej (zw. Matką Boską Goźlińską) przekazanego przez założyciela zakonu ks. Stanisława Papczyńskiego (1631-1701), zachowała się kompletna późnorokokowo-

\footnotetext{
26 Dumała K., Studia z dziejów Szydłowca, „Rocznik Muzeum Świętokrzyskiego”, 4: 1967, s. 177-260; Puget W., Z dziejów zamku w Szydłowcu, „Rocznik Muzeum Świętokrzyskiego”, 4: 1967, s. 261-302; Zamek szydłowiecki i jego właściciele. Materiały sesji popularnonaukowej 24 lutego 1996 roku, red. J. Wijaczka, Szydłowiec 1996, s. 125-152; Zdon W., Zamek w Szydłowcu - wyniki i wnioski z ,badań" architektonicznych, [w:] Zamek szydłowiecki i jego właściciele. Materiały sesji popularnonaukowej 24 lutego 1996 roku, red. J. Wijaczka, Szydłowiec 1996, s. 21-35.
} 
klasycystyczna dekoracja iluzjonistyczna wnętrza (Ryc. 13). Obecny, drugi kościół w kształcie bazyliki transeptowej z dwuwieżową fasadą wzniesiono z drewna w 1776 r., natomiast czas powstania samej dekoracji przypadł na ostatnie lata XVIII wieku. Za przypuszczalnego autora iluzjonistycznej dekoracji uznaje się wybitnego członka tego zakonu ks. Jana Niezabitowskiego $(1744-1804)^{27}$.

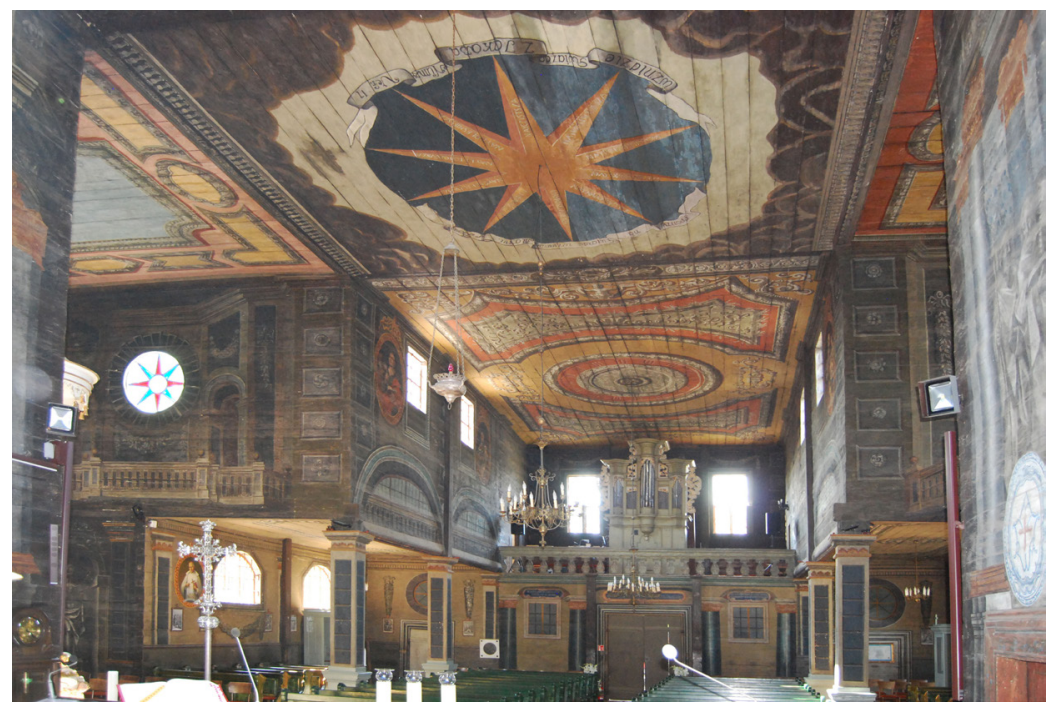

Fot. 13 Porzecze Mariańskie, kościół drewniany, stan w 2016 roku. Widok wnętrza. Fot. J. Lewicki

\section{Rola WKZ w ochronie i zarządzaniu pomnikami historii}

Najważniejszą rolą Wojewódzkiego Konserwatora Zabytków jest pełnienie nadzoru konserwatorskiego nad zabytkami znajdującymi się na terenie pomnika historii. W ten sposób WKZ może upowszechniać wysokie standardy prowadzonych prac konserwatorskich i tworzyć wzorce ochrony i konserwacji na tym obszarze, a także prowadzić działania promocyjne. Niezmiernie ważną rolą jest też inicjowanie działań na rzecz uznania zabytku za pomnik historii. Mimo narzuconych prawnie ograniczeń Wojewódzki Konserwator Zabytków może aktywnie działać na rzecz ochrony pomników historii. Może też być wykonawcą polityki państwa dotyczącej narodowego dziedzictwa. Może bardzo sprawnie łączyć zrównoważony rozwój obszarów pomników historii z ochroną konserwatorską i z rozwojem oraz przystosowaniem ich do zmieniających się potrzeb i warunków życia.

27 Piwocki K., Restauracja malowideł w kościółku drewnianym w Goźlinie, „Biuletyn Naukowy", 1933, nr 4, s. 237; Piwocki K., Kościół w Goźlinie i jego polichromia, „Sprawozdania Towarzystwa Naukowego we Lwowie", 1934, nr 1, s. 37-39; Galicka I., Sygietyńska H., Jan Niezabitowski - malarz mariański, „Biuletyn Historii Sztuki", 36: 1974, nr 3, s. 269-280; Galicka I., Sygietyńska H., Odkrywanie sztuki. Sztuka odkrywania, Warszawa 1994. 


\section{Bibliografia}

\section{Źródła internetowe}

https://www.nid.pl/pl/Informacje_ogolne/Zabytki_w_Polsce/Pomniki_historii/Lista_miejsc/ miejsce.php?ID=317, data wejścia $15 \mathrm{~V} 2019$.

https://www.nid.pl/pl/Informacje_ogolne/Zabytki_w_Polsce/Pomniki_historii/Lista_miejsc/ miejsce.php?ID=324, data wejścia 15 V 2019.

https://www.nid.pl/pl/Informacje_ogolne/Zabytki_w_Polsce/Pomniki_historii/Lista_miejsc/ miejsce.php?ID=318, data wejścia 15 V 2019.

https://www.nid.pl/pl/Informacje_ogolne/Zabytki_w_Polsce/Pomniki_historii/Lista_miejsc/ miejsce.php?ID=2398, data wejścia $15 \mathrm{~V} 2019$.

https://www.nid.pl/pl/Informacje_ogolne/Zabytki_w_Polsce/Pomniki_historii/Lista_miejsc/ miejsce.php?ID=3753, data wejścia 15 V 2019.

https://www.nid.pl/pl/Informacje_ogolne/Zabytki_w_Polsce/Pomniki_historii/Lista_miejsc/ miejsce.php?ID=3934, data wejścia 15 V 2019.

\section{Akty prawne}

Rozporządzenie Prezydenta RP z dnia 4 stycznia 2012 r. w sprawie uznania za pomnik historii „Warszawa - Zespół Stacji Filtrów Williama Lindleya”, Dz. U., 18 stycznia 2012, poz. 64.

Rozporządzenie Prezydenta RP z dnia 4 stycznia 2012 r. w sprawie uznania za pomnik historii „Żyrardów - XIX-wieczna Osada Fabryczna”, Dz. U., 1912, Nr 11, poz. 59.

Rozporządzenie Prezydenta RP z dnia 3 lipca 2014 r. w sprawie uznania za pomnik historii „Warszawa - zespół zabytkowych cmentarzy wyznaniowych na Powązkach”, Dz. U., 21 lipca 2014, poz. 956.

Rozporządzenie Prezydenta RP z dnia 20 kwietnia 2018 r. w sprawie uznania za pomnik historii „Płock - Wzgórze Tumskie”, Dz. U., 24 maja 2018, poz. 1003.

Rozporządzenie Prezydenta RP z dnia 10 grudnia 2018 r. w sprawie uznania za pomnik historii „Pułtusk - kolegiata pod wezwaniem Zwiastowania Najświętszej Maryi Panny”, Dz. U., 29 grudnia 2018, poz. 2462.

Zarządzenie Prezydenta RP z 8 września 1994 r. w sprawie uznania za pomnik historii, „Monitor Polski", 1994, nr 50, poz. 423. 


\section{Publikacje}

Architektura gotycka w Polsce, red. T. Mroczko i M. Arszyński, Warszawa 1995, T. 2, Katalog zabytków, s. 51-52, 304, 371.

Bieniewska B., Liczbiński A., Prace konserwatorskie w województwie warszawskim w latach 19531954, „Ochrona Zabytków”, 8: 1955, z. 1, s. 57-62.

Bieniewska B., Zakres i problematyka prac konserwatorskich (1945-1958), „Biuletyn Konserwatorski Województwa Warszawskiego", Warszawa 1958, s. 7-64.

Brykowska M., W sprawie architektury zespołu pobenedyktyńskiego w Opactwie-Sieciechowie, „Kwartalnik Architektury i Urbanistyki”, XV: 1970, z. 2, s. 203-211.

Czersk Wzgórze Zamkowe Badania 1974-1983, P. Urbańczyk (red.), Warszawa 2016.

Dąbrowski K., Konserwacja malowideł ściennych w Czerwińsku: odkrycie romańskiej polichromii, „Ochrona Zabytków”, 4: 1951, nr 3-4, s. 127-132.

Dąbrowski K., Problemy konserwatorskie romańskiej polichromii w Czerwińsku, „Biuletyn Historii Sztuki", 15: 1953, nr 2, s. 75-76.

Dumała K., Studia z dziejów Szydłowca, „,Rocznik Muzeum Świętokrzyskiego”, 4: 1967, s. 177-260.

Dzierzwicki P., Bieniewska B., Liczbiński A., Prace konserwatorskie w województwie warszawskim w latach 1953-1954, „Ochrona Zabytków”, 8: 1955, z. 1, s. 62.

Gacki J., Benedyktyński klasztor w Sieciechowie według pism i podań miejscowych przez..., Radom 1872.

Galicka I., Sygietyńska H., Jan Niezabitowski - malarz mariański, „Biuletyn Historii Sztuki", 36: 1974, nr 3, s. 269-280.

Galicka I., Sygietyńska H., Odkrywanie sztuki. Sztuka odkrywania, Warszawa 1994.

Gawarecki W. H., Opis kościoła w Krasnem, i w nim będących nagrobków familii Krasińskich, [w:] idem, Pamiętnik Historyczny Płocki, t. II, 1830, s. 100-139.

Guerquin B., Zamki w Polsce, Warszawa 1984, s. 132-134, 298-300.

Kajzer L., Kołodziejski S., Salm J., Leksykon zamków w Polsce, red. nauk. L. Kajzer, Warszawa 2012, s. 140-143, 483-487.

Karczewski A., Czersk, Warszawa 1939.

Karpowicz M., Cuda Węrowa, Węgrów 2009.

Karpowicz M., Działalność artystyczna Michelangela Palloniego w Polsce, Warszawa 1967.

Karpowicz M., Sztuka oświeconego sarmatyzmu, Warszawa 1986.

Karpowicz M., Sztuka Warszawy czasów Jana III, Warszawa 1987.

Katalog zabytków sztuki w Polsce, Tom III, Województwo Kieleckie, zeszyt 10, powiat radomski, Warszawa 1961.

Krawczyk M., W. Stan, Bernardyni radomscy. Zarys dziejów, Radom 2013. 
Lewicki J., Dzieje i architektura zamku w Ilży. Problematyka badawcza i konserwatorska [w:] Siedziby biskupów krakowskich na terenie dawnego Województwa sandomierskiego, red. L. Kajzer, Kielce 1997, s. 57-83.

Luboński J., Monografia historyczna miasta Radomia, Radom 1907, s. 122-130.

Miasto w nowej odsłonie. Monografia Iłży, t. 1, Od czasów najdawniejszych do 1945 roku, pod red. S. Piątkowskiego, Warszawa 2014.

Miszczak D., Późnobarokowy kościół pobenedyktyński w Sieciechowie-Opactwie, „Rocznik Muzeum Świętokrzyskiego", IX: 1975, s. 367-383.

Mroczko T., Czerwińsk romański, Warszawa 1972.

Nowakowski P., Itża miasto kościelne, Radom 2012.

Efrem A. Obruśnik OFM, Zespół kościoła i klasztoru Ojców Bernardynów w Radomiu, „Biuletyn Kwartalny Radomskiego Towarzystwa Naukowego", XXXIX: 2004, z. 1-4, s. 109-128.

Omilanowska M., Architekt Stefan Szyller 1857-1933, Warszawa 2008; Nowiński J., Czerwińsk, Warszawa 2012.

Osiecka-Samsonowicz H., Freski Sebastiana Ecksteina w kościele w Krasnem, „Mazowsze”, 1996, nr 1, s. 31-36.

Piwocki K., Kościót w Goźlinie i jego polichromia, „Sprawozdania Towarzystwa Naukowego we Lwowie", 1934, nr 1, s. 37-39.

Piwocki K., Restauracja malowideł w kościółku drewnianym w Goźlinie, „Biuletyn Naukowy", 1933, nr 4, s. 237.

Prószyńska Z., Mańkowski Szymon, [w:] Słownik artystów polskich i obcych w Polsce działających. Malarze - rzeźbiarze - graficy, t. 5, po red. J. Derwojeda, Warszawa 1993, s. 338-340.

Puget W., Z dziejów zamku w Szydłowcu, „Rocznik Muzeum Świętokrzyskiego”, 4: 1967, s. 261-302. Słowiński K., Bogu i ludziom: parafia i kościół p.w. Wniebowzięcia Najświętszej Marii Panny w Wegrowie w XV-XXI wieku, Radom 2011.

Stawski M., Opactwo czerwińskie wśredniowieczu. Opactwo kanoników regularnych w Czerwińsku w średniowieczu, Warszawa 2007.

Świechowski Z., Ścienne malowidła romańskie w Czerwińsku, „Biuletyn Historii Sztuki”, 15: 1953, nr 2, s. 64-74.

Wegrów: dzieje miasta i okolic w latach 1441-1944: praca zbiorowa, pod red. A. Kołodziejczyka i T. Swata, Towarzystwo Miłośników Ziemi Węgrowskiej, Węgrów 1991.

Wiśniowski E., Z dziejów opactwa benedyktyńskiego w Sieciechowie (XIII-XVII w.), „Roczniki Humanistyczne KUL", t. 7: 1958, z. 2, Lublin 1960, s. 23-120.

Wiśniewski J., Dekanat Radomski, Radom 1911, s. 237-368.

Wojciechowski A., Sieciechów - studium historyczno-urbanistyczne, PKZ Lublin 1982, mps.

$Z$ dziejów budownictwa rezydencjonalno-obronnego na ziemi iłżeckiej, red. D. Kalina, R. Kubicki, Kielce-Iłża 2011. 
Zagrodzki T., Czersk. Zamek i miasto historyczne, Warszawa 1988, s. 128-135.

Zamek szydłowiecki i jego właściciele. Materiały sesji popularnonaukowej 24 lutego 1996 roku, red. J. Wijaczka, Szydłowiec 1996, s. 125-152.

Zdon W., Dydaktyka zbawienia na sklepieniach pobenedyktyńskiego kościoła w opactwie sieciechowskim, „Arteria - Rocznik Katedry Sztuki Wydziału Nauczycielskiego Politechniki Radomskiej" 2008, nr 6, s. 33-38.

Zdon W., Świątynia jako miejsce na granicy przemijania i wiecznej szczęśliwości, czyli o znaczeniu campanulli w architekturze kościoła opackiego w Sieciechowie, [w:] Obraz i przyroda, red. M. Mazurczak, J. Patyra, M. Żak, Lublin 2005, s. 549-559.

Zdon W., Zamek w Szydłowcu - wyniki i wnioski z ,badań” architektonicznych, [w:] Zamek szydłowiecki i jego właściciele. Materiały sesji popularnonaukowej 24 lutego 1996 roku, red. J. Wijaczka, Szydłowiec 1996, s. 21-35. 
